\title{
Trigonum Olfactorium
}

National Cancer Institute

\section{Source}

National Cancer Institute. Trigonum Olfactorium. NCI Thesaurus. Code C33813.

The flattened, triangular portions of the olfactory tract located near the anterior perforated substance in the brain. 